\title{
INVESTIGATION OF TOXICITY, ANTIMICROBIAL ACTIVITY AND COUGH TREATMENT OF PRODUCTS PRODUCED FROM Pouzolzia zeylanica PLANTS GROWING IN VIETNAM
}

\author{
NGUYEN DUY TAN ${ }^{1 *}$ and VO THI XUAN TUYEN ${ }^{2 *}$ \\ 1,2Faculty of Agriculture and Natural Resources, An Giang University, VNU-HCM, Vietnam \\ *E-mail:ndtan@agu.edu.vn ornguyenduytanagu@gmail.com
}

Accepted 21 September 2020, Published online 25 October 2020

\begin{abstract}
Pouzolzia zeylanica (L.) Benn is one of the medicinal plants that possess a lot of bioactive compounds with potential for therapeutics. These plants have usually been consumed in traditional way despite its efficacy and safety proven. The objectives of this study were to evaluate the toxic and pharmacological effects of concentrated and spray-dried extract of Pouzolzia zeylanica. The plant is popular for its auxiliary substances in the treatment of cough; however, the information about the safety of their usage need to be explored. In the study, the antibacterial ability of respiratory, acute oral toxicity, effects of reducing sputa and cough symptom were evaluated. The antibacterial ability of the test product was assessed on 5 strains of respiratory tract pathogenic bacteria by minimum inhibitory concentration (MIC) method. The acute oral toxicity, effect to reduce sputum and cough treatment was tested in mice through capsaicin model following standardized methods. It was observed that both products were not causing acute oral toxicity. Pouzolzia zeylanica spray-dried powder had antibacterial activity on Streptococcus pyogenes with MIC of $50 \mathrm{mg} / \mathrm{mL}$. Dose, which used (6 g/day converted in humans) showed effect on reducing sputa and cough symptom due to stimulation of cough model with capsaicin. In contrast, the concentrated product did not show antimicrobial activity in tested bacterial strains. Dose at $4 \mathrm{~g} /$ day converted in humans showed effect on reducing sputa in experimental mice that were affected with capsaicin. Nevertheless, the effect of it on cough symptoms caused by the capsaicin model was not typical in comparison with spray dried powder. Result showed that spray-dried powder did not exhibit acute oral toxicity, had antibacterial properties, reduced sputum and treated cough. This promises that it can be developed into a convenient instant tea product, supporting good health for consumers in preventing diseases.
\end{abstract}

Key words: Pouzolzia zeylanica, concentrated and spray-dried products, toxicity, pharmaceutic, experimental mice

\section{INTRODUCTION}

Plants have been used in traditional medicine for several centuries. From ancient times, people have been exploring and using various plants and plant products to cure many different diseases. Several plants are currently undergoing investigation to determine their therapeutic efficacy and many plant species are traditionally used for respiratory illness treatment. Respiratory diseases can be caused by several reasons, such as the presence of microorganisms or toxins in the environment, which generally attack weak organisms with nutritional deficiencies. The most common related respiratory illness symptoms are tonsillitis, bronchitis, pneumonia and influenza. The main symptoms of

* To whom correspondence should be addressed. these disorders are often very similar and are manifested in the following ways: flushing, cough, fever, headache and sore throat (Shah et al., 2015).

Many plants are used in phytotherapic preparations without standard quality control. Some studies have showed the presence of secondary metabolites with toxic and carcinogenic potential when used chronically (Ernest, 2004; Rietjens et al., 2005). The toxicological studies on effects of medicinal plants on human health have been conducted deliberately (Simão et al., 2014).

Pouzolzia zeylanica is a medicinal plant, which is located in tropical and subtropical regions. It has been used as one of the components in herbal remedies for treating various diseases. In Vietnam, this plant was popularly cultivated in Mekong Delta region. The plant is commonly used as fresh or dried plant, decoction drunk to treat cough up phlegm, 
pulmonary tuberculosis, sore throat, enteritis, dysentery, diuretic, anti-inflammation, urinary infections, galactopoietic, pulmonary disease, etc (Vo Van Chi, 2012). In addition, people from many Asian countries have used it to treat various kinds of diseases by traditional method such as poultice to bone fractures (Ratnam \& Raju, 2008), boils and to relieve stomachache (Yusuf et al., 2006), diabetes (Mondal et al., 2013), cancer (Sandhya et al., 2013), treat eyes injuries (Purkayastha et al., 2007), itching, dysentery and loose stools of infant (Bhattacharjya \& Borah, 2008), cure stomach ailments, preventive radiation and confirmed the therapeutic value of polyphenols contained in the leaves ( $\mathrm{Li}, 2006)$. In modern medicine, Pouzolzia zeylanica is also combined with other herbs that have ability to fight cancer cells, against tuberculosis and good effect on lungs (Le, 2007).

The objectives of this study were to determine antibacterial ability of respiratory, acute oral toxicity, effect of reducing sputa and cough symptom of two products (concentrated and spraydried) made from extraction of Pouzolzia zeylanica plants.

\section{MATERIALS AND METHODS}

\section{Preparation of products for test}

Pouzolzia zeylanica was collected from experimental area of An Giang University, Vietnam in March 2015 and harvested after one and a half month of cultivation, with $20-30 \mathrm{~cm}$ in height. The whole plant was then cleaned with tap-water, dehydrated by sun drying until the final moisture content about $12 \%$, cut into small pieces about 2-3 cm long. The optimal extraction conditions of dried plants were performed at $81^{\circ} \mathrm{C}$ for $30 \mathrm{~min}$ and water/material ratio of $27 / 1 \mathrm{v} / \mathrm{w}$. The hot extract was filtered through cotton cloth and determined their volumes. After that, the extract was blended with citric acid of $0.29 \%, 20^{\circ}$ Brix by sucrose and $0.29 \%$ carboxymethyl cellulose; vacuum cooking at $600 \mathrm{mmHg}$ for $40 \mathrm{~min}$, the final product was $60^{\circ}$ Brix (concentrated product). The extracted compound was blended with $9 \%$ maltodextrin and $0.08 \%$ arabic gum. Later, spray dried process was conducted at inlet drying temperature of $179^{\circ} \mathrm{C}$, feed flow rate of $18 \mathrm{rpm}$, the moisture of obtained powder was $6.5 \%$ (spray-dried product). They were packaged and stored at room temperature for further experiments.

\section{Source of experimental organisms}

The bacterial strains selected for this study were Staphylococcus aureus (ATCC12600), Streptoccocus pyogenes (ATCC12344), Streptococcus pneumoniae (ATCC27336), Klebsiella pneumoniae (ATCC70063),
Pseudomonas aeruginosa (ATCC9027). These bacterial strains were stored at Medicine and Pharmacy University in Ho Chi Minh City, Vietnam. Male and female white mice, Swiss albino strains, average weight $20 \pm 2 \mathrm{~g}$ were provided by Nha Trang Institute of Vaccines and Medical Biologicals, Vietnam. Mice were raised with pelleted foods, drinking water sufficiently and were kept stable for at least a week before the test.

\section{Experimental designs}

\section{Quantify the antibacterial capacity of the product by the Minimum Inhibitory Concentration method}

Experimental bacteria were cultivated on Mueller Hinton Agar (MHA) medium at $37^{\circ} \mathrm{C}$ for $24 \mathrm{hr}$. About 3-4 colonies of bacteria transferred into a test tube containing $10 \mathrm{~mL}$ of Mueller Hinton Broth (MHB), incubated for $4-6 \mathrm{hr}$ at $37^{\circ} \mathrm{C}$ until the absorbance at $625 \mathrm{~nm}$ was measured with a cuvette $(1 \mathrm{~cm})$ to reach $0.08-0.10$; corresponding to about $10^{8} \mathrm{CFU} / \mathrm{mL}$. This bacterial suspension was diluted to a density of $10^{7} \mathrm{CFU} / \mathrm{mL}$ with sterile buffer solution. After dilution, the bacteria suspension was proceed for further testing within $15 \mathrm{~min}$. Two test products were diluted in MHA medium, which were melted and allowed to cool to about $50^{\circ} \mathrm{C}$. Accurately weighed $500 \mathrm{mg}$ of the test product was put into a sterile test tube No.1. Subsequently, about $10 \mathrm{~mL}$ MHA was added into the mixture and then strongly vortexed to mix the mixture well and to obtain a test product concentration of $50 \mathrm{mg} / \mathrm{mL}$. Later, approximately $5 \mathrm{~mL}$ was taken from tube No.1 and transferred to test tube No.2 containing $5 \mathrm{~mL}$ of MHA medium. serial dilution 1/2 was continued as above to test tube number 10 to obtain a range of medium containing diluted test product $1 / 2$ gradually. Test tubes containing MHA was poured into petri dishes, cooled to solidify. When medium solidified, about $1 \mu \mathrm{l}$ of the above prepared bacterial suspension was streaked onto the surface of all agar plates. The plates were then incubated at $37^{\circ} \mathrm{C}$ for $24 \mathrm{hr}$. The trace of bacteria growing at the implantation point and MIC was recorded (Patel et al., 2015).

\section{Oral route toxicity investigation}

Male and female white mice were starved for $16 \mathrm{hr}$ and divided into similar groups. Mice in the same batch would receive the same dose of the survey. The volume of oral dose was $20 \mathrm{~mL} / \mathrm{kg}$ of mouse weight and no more than $0.5 \mathrm{~mL} / \mathrm{rat} / \mathrm{time}$. The assessment based on the reactive or incapacitated (life or death) was found in each mouse in the group after $72 \mathrm{hr}$. The mice were followed up after 14 days of drinking to recognize abnormal symptoms (if any) (Do, 1996; National Institute of Medicinal Materials, 2006). 


\section{Survey reducing ability of phlegm}

White male mice with Swiss albino strains, 5-6 weeks of age, were randomly divided into 6 experiments group $(\mathrm{n}=8-10)$ as follows: batches of control (drinking distilled water), test batches 1 and 2 were given drinking concentrated product with dose equivalent to $1 / 10$ and $1 / 20 \mathrm{D}_{\max }$, test batches 3 and 4 were given drinking spray-dried powder samples equivalent to $1 / 10$ and $1 / 20 \mathrm{D}_{\max }$ and batches of reference (positive) drinking ambroxol (capsule Ambroxol ${ }^{\circledR}$, containing ambroxol $\mathrm{HCl}$ $30 \mathrm{mg}$, DOMESCO Pharmaceutical Joint Stock Company (Vietnam), lot number 0050316, expecting March 5, 2019) dose of $240 \mathrm{mg} / \mathrm{kg}$. Samples and ambroxol were dissolved in distilled water and given to mice with an oral volume of $10 \mathrm{ml} / \mathrm{kg}$ of mouse weight, continuously for 3 days and given once a day. One hour after the final drink, mice were injected with $2.5 \%$ phenol red solution in physiological saline. After 30 min of injection with phenol red, the mice were euthanized and the trachea was separated, immediately placed in the test tube containing $2 \mathrm{~mL}$ of physiological saline and placed in the ultrasonic tank for $15 \mathrm{~min}$. Then $2 \mathrm{~mL}$ of $5 \%$ sodium bicarbonate solution was added and the mixture was measured absorbance at $558 \mathrm{~nm}$. Expectorant effect was assessed by increasing the optical density in the test plots or the lot compared to the control batch by the formula: Percentage of phenol red secretion $\left.(\%)=\left[\left(\mathrm{Dt}-\mathrm{D}_{0}\right) / \mathrm{D}_{0} \times 100\right)\right]$, where $\mathrm{Dt}$ is the optical density measured in the test lot, $\mathrm{D}_{\mathrm{o}}$ is the optical density measured in the control lot (Engler \& Szelenyi, 1984; Dapaah et al., 2016).

\section{Investigation of cough suppressant effects}

White male mice with Swiss albino strains, 5-6 weeks of age, were randomly divided into 6 experiments group $(n=8-10)$ as follows: batches of control (drinking distilled water), test batches 1 and 2 were given drinking concentraed product with equivalent to $1 / 10$ and $1 / 20 \mathrm{D}_{\max }$, batches 3 and 4 were given drinking spray dried powder sample with doses equivalent to $1 / 10$ and $1 / 20 \mathrm{D}_{\max }$ and comparison batches (positive) Neo-codion $\AA$ tablets (film tablets containing codeine camphosulfonate $25 \mathrm{mg}$ equivalent to codeine $14.93 \mathrm{mg}$, sulfogaiacol $100 \mathrm{mg}$ and $20 \mathrm{mg}$ Grindélia extract) dose of 1 tablet $/ \mathrm{kg}$. The test and positive samples were dissolved in distilled water and given to the mice orally at dose of $10 \mathrm{~mL} / \mathrm{kg}$ of mouse weight once daily for 3 days. Two hours after the last drink, mice were placed in glass jars (similar in size to desiccators, vented) and exposed to capsaicin (Sigma-Aldrich, USA, mixed in ethanol $10 \%$ +Tween-80 10\%) aerosol form at a concentration of $100 \mathrm{mM}$ for $10 \mathrm{~min}$ with an injection volume of $0.25 \mathrm{~mL} / \mathrm{min}$. The potential for cough, number of coughs and behavioral symptoms of the mouse (sniffing-scratching the muzzle, jumping up by strong stimulation) for $10 \mathrm{~min}$ were identified. Later, mice trachea were separated and the phenol red assay was performed similar as content of survey reducing ability of phlegm (Nieto et al., 2003; Tanaka \& Maruyama, 2005; Canning, 2008; Zhang et al., 2009; Satia et al., 2017).

\section{Statistical analysis}

The results obtained in the tests are indicated by the average (Mean \pm SEM) of replication $(n=8$ 10) and statistical analysis of data based on the Ttest or One-way ANOVA tests followed by StudentNewman test- Keuls, with $95 \%$ reliability $(p<0.05)$ with SigmaStat ${ }^{\circledR}$ ver software. 3.5 (SYSTAT Software Inc., Richmond, CA, USA).

\section{RESULTS AND DISCUSSION}

\section{The antibacterial capacity of two test products}

Survey of antimicrobial activity of medicinal plants can be used in many different assessment methods. But the method of minimum inhibitory concentration (MIC) and agar well diffusion (AWD) are the two most commonly used methods (Anyanwu \& Okoye, 2017). MIC assessment is a quantitative method of measuring antibacterial activity based on the principle of contact between bacteria with a range of different diluted test substances concentrations. MIC is the lowest concentration of antimicrobial substances that prevent bacterial growth under known conditions (Nasir et al., 2015). AWD method is used because it is possible to indicate plant extract concentration that affects the structural and functional morphology of the test bacteria, based on the principle of contact between test bacteria and equal volume of test substances. Each of the test substances had different concentrations pumped into wells of equal depth on agar medium. Differences in the data collected using MIC assessment may be influenced by factors such as the concentration of the test substance, the type of development medium of bacterium, the incubation time and the method of preparation of the test substance (Balouiri et al., 2016).

Test results of samples diluted with a concentration from 50 to $0.1 \mathrm{mg} / \mathrm{mL}$ on bacterial strains in Table 1 showed that most of the bacteria were not inhibited (-) at the concentrations used, except for Streptococcus pyrogenes $(+)$ at the concentration of spray dried powder $50 \mathrm{mg} / \mathrm{mL}$ (Figure 1). This could be explained as the survey concentration of the sample was not enough to inhibit bacteria because both spray dried and concentrated products made from aqueous extract, concentration of bioactive compounds in the product was relatively low. 
Table 1. The results determine the antibacterial activity of two test samples

\begin{tabular}{|c|c|c|c|c|c|c|c|c|c|c|c|}
\hline \multirow{2}{*}{ Bacterial strains } & \multirow{2}{*}{ Control } & \multicolumn{10}{|c|}{ Concentrate product $(\mathrm{mg} / \mathrm{mL})$} \\
\hline & & 50 & 25 & 12.5 & 6.25 & 3.13 & 1.56 & 0.78 & 0.39 & 0.20 & 0.10 \\
\hline S. aureus & - & - & - & - & - & - & - & - & - & - & - \\
\hline S. pyogenes & - & - & - & - & - & - & - & - & - & - & - \\
\hline S. pneumoniae & - & - & - & - & - & - & - & - & - & - & - \\
\hline K. pneumoniae & - & - & - & - & - & - & - & - & - & - & - \\
\hline$P$. aeruginosa & - & - & - & - & - & - & - & - & - & - & - \\
\hline \multirow{2}{*}{ Bacterial strains } & \multirow{2}{*}{ Control } & \multicolumn{10}{|c|}{ Spray-dried powder $(\mathrm{mg} / \mathrm{mL})$} \\
\hline & & 50 & 25 & 12.5 & 6.25 & 3.13 & 1.56 & 0.78 & 0.39 & 0.20 & 0.10 \\
\hline S. aureus & - & - & - & - & - & - & - & - & - & - & - \\
\hline S. pyogenes & - & + & - & - & - & - & - & - & - & - & - \\
\hline S. pneumoniae & - & - & - & - & - & - & - & - & - & - & - \\
\hline K. pneumoniae & - & - & - & - & - & - & - & - & - & - & - \\
\hline$P$. aeruginosa & - & - & - & - & - & - & - & - & - & - & - \\
\hline
\end{tabular}

Note: (-) no antimicrobial activity; (+) shows antibacterial activity.

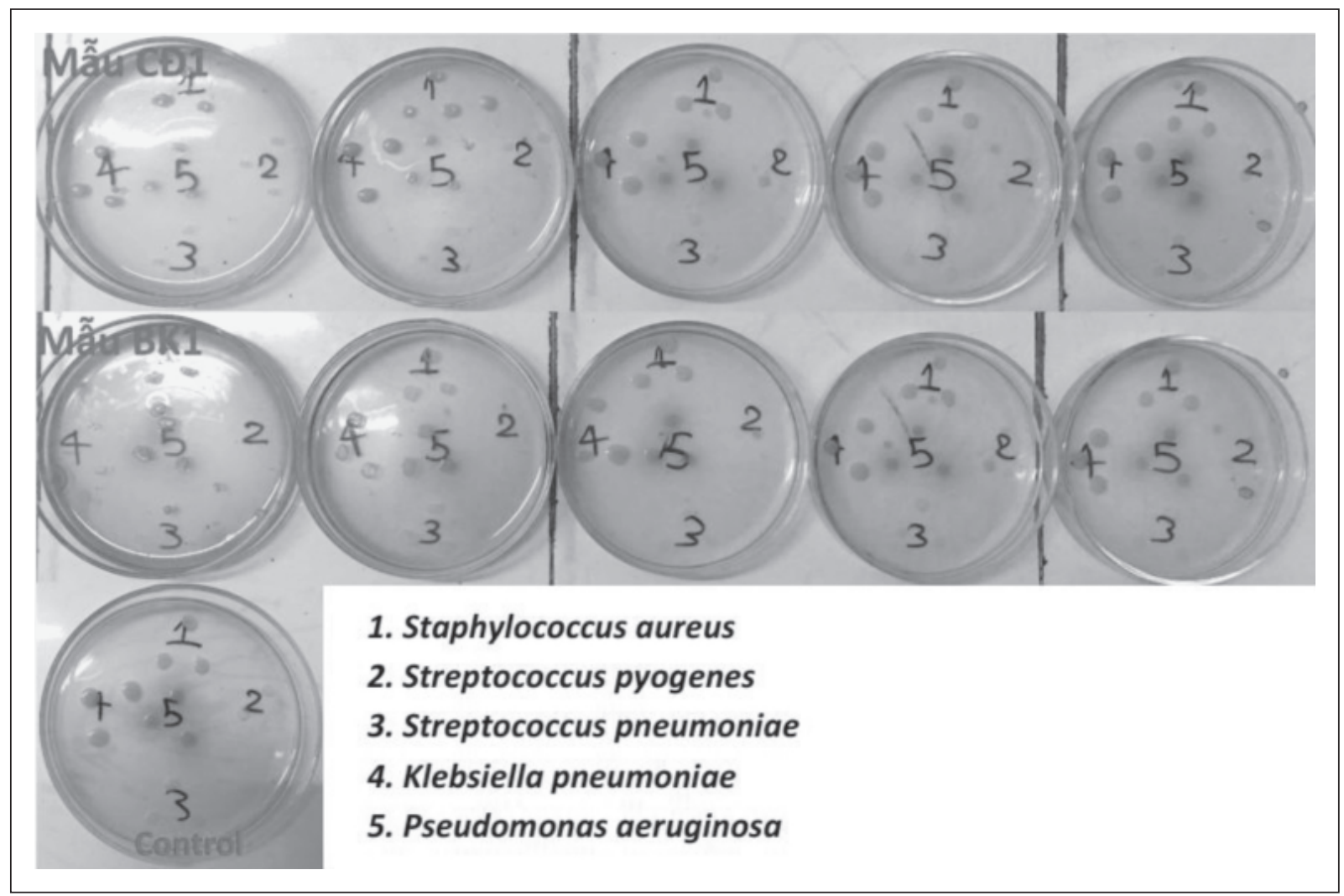

Fig. 1. Antibacterial test samples by MIC method.

In reported studies, the low concentration of the test sample could inhibit the activity of bacteria. Foe example aqueous extract from leaves of Amaranthus hybridus with MIC of $6.33 \mathrm{mg} / \mathrm{mL}$ (Nduche et al., 2016); and methanol and ethanol extract of Allium ascalonicum, Terminalia glaucescens, Allium cepa, and ethanol extract of Securidaca longepedunculata with MIC of $50 \mathrm{mg} /$ $\mathrm{mL}$ (Adeleye et al., 2008). Research of Bello et al.
(2011) showed aqueous extract from Pavetta crassipes with antibacterial activity of $P$. aeruginosa, $S$. pyogenes, $K$. pneumoniae and $N$. gonorrhoeae with MIC from 6.25-12.5 mg/mL. Antimicrobial activity (P. aeruginosa, S. aureus, E. coli, $K$. pneumoniae) and mold (A. niger, $C$. albicans) of ethanol extract from $C$. alata Linn (Leguminosae) seed had the inhibitory concentration of $6.25-50 \mathrm{mg} / \mathrm{mL}$ (Okwu \& Nnamdi, 
Table 2. MIC of two test samples in survey condition

\begin{tabular}{lcc}
\hline \multirow{2}{*}{ Baterial strains } & \multicolumn{2}{c}{ MIC $(\mathrm{mg} / \mathrm{mL})$} \\
\cline { 2 - 3 } & Concentrate product & Spray-dried powder \\
\hline Staphyloccocus aureus & - & - \\
Streptoccocus pyogenes & - & 50 \\
Streptoccocus pneumoniae & - & - \\
Klebsiella pneumoniae & - & - \\
Pseudomonas aeruginosa & - & - \\
\hline
\end{tabular}

Note: (-) not determine activity.

2011). The methanol extract from G. latifolium leaves had an inhibitory MIC of $P$. monteilli of $75 \mathrm{mg} / \mathrm{mL}$ (Ikegbunam et al., 2014). The ethanol extract of Evolvulus alsinoides had MIC from 16 $\mathrm{mg} / \mathrm{mL}$ to $512.5 \mathrm{mg} / \mathrm{mL}$; lowest in $S$. typhi and highest in $B$. cereus and $S$. aureus (Omogbai \& Eze, 2011). Extracts from Uritca dioica at a concentration of $100 \mathrm{mg} / \mathrm{mL}$ showed antimicrobial activity but no antifungal activity (ModarresiChahardehi et al., 2012). Minimum inhibitory concentration values of plant extracts inhibit bacteria with different concentrations depending on the kind of various plants, the solvent used and the test strain (Van-Vuuren, 2015).

The results in Tables 1 and 2 showed that the spray-dried powder sample with MIC on the Streptoccocus pyogenes strain was $50 \mathrm{mg} / \mathrm{mL}$. The test samples did not exhibit antimicrobial activity on other bacterial strains.

\section{Oral route toxicity of two test products}

After $72 \mathrm{hr}$ of testing, the maximum recommended dose of the test sample (concentrated product) on white mice was $20 \mathrm{~g} / \mathrm{kg}$ of mouse weight, with a death rate of $0 \%$ and $\mathrm{LD}_{50}$ could not be determined. Therefore, the highest dose mouse can drink without causing the death $\left(D_{\max }\right), D_{\max }=$ $20 \mathrm{~g} / \mathrm{kg}$ body weight of mouse could be determined. The maximum dose of the test sample (spray dried powder) on white mice was $30.12 \mathrm{~g} / \mathrm{kg}$ of mouse weight, with a death rate of $0 \%$ and could not be determined $\mathrm{LD}_{50}$. Therefore, $\mathrm{D}_{\max }=30.12 \mathrm{~g} / \mathrm{kg}$ of mouse weight could be determined.

Test samples (concentrated product and spraydrying powder) did not exhibit oral acute toxicity on white mice; all mice were still eating and living normally during $72 \mathrm{hr}$ of observation. Mice were followed up after 14 days of drinking and abnormal symptoms were not noticed. The results of general anatomy of internal organs of liver, heart, lungs, stomach, kidneys showed no abnormal signs (Table 4). Based on the results of the oral toxicity assessment, the safe therapeutic dose range for pharmacological tests was determined (Table 3 ).
Table 3. Dose selected for pharmacological tests

\begin{tabular}{lcc}
\hline \multirow{2}{*}{ Test samples } & \multicolumn{2}{c}{ Dose $(\mathrm{g} / \mathrm{kg})$} \\
\cline { 2 - 3 } & $1 / 10 \mathrm{D}_{\max }$ & $1 / 20 \mathrm{D}_{\max }$ \\
\hline Concentrate product & 2.0 & 1.0 \\
Spray-dried powder & 3.0 & 1.5 \\
\hline
\end{tabular}

Reducing ability of phlegm of two test products

The ambroxol is a metabolite product which has active bromhexine, acts to destroy mucus that accumulates in the bronchial wall and increase their excretion through the active function of villi. Ambroxol alters the structure of bronchial secretions by reducing and cutting mucopolysaccharide fibers, reducing synthesis sulfomucin of cells, so the phlegm spitting becomes easier. The concentrated product (dose of $1.0 \mathrm{~g} / \mathrm{kg}$ ) and spray-dried powder from the Pouzolzia zeylanica extract (dose of 1.5 $\mathrm{g} / \mathrm{kg}$ ) all showed the effect of increasing the red phenol secretion in the white mouse trachea, reaching statistical significance $(p<0.05)$ compared to the control group and similar to the effect of ambroxol (Table 5). In high concentration of concentrated product $(2.0 \mathrm{~g} / \mathrm{kg})$ and spray-dried powder $(3.0 \mathrm{~g} / \mathrm{kg})$ from the Pouzolzia zeylanica extract did not show the effect of increasing phenol red secretion in the white mice trachea $(p>0.05)$. It might be due to reverse inhibitory reaction. Therefore, dose of $1.0 \mathrm{~g} / \mathrm{kg}$ and $1.5 \mathrm{~g} / \mathrm{kg}$ of test samples were selected for the study of the effect of two Pouzolzia zeylanica products on capsaicin cough models.

Besides, results in Table 5 showed that capsaicin reduces phenol red secretion in the white mice trachea of the untreated group (capsaicin control group), achieving statistical significance compared to the physiological control group. Neocodion ${ }^{\circledR}$ drugs increased phenol red secretion of mice trachea that caused cough with capsaicin, with increasing 54,55\% and statistical significance compared to the batch of capsaicin, indicating the effect of reducing phlegm. The ingredients in Neo- 
Table 4. Results of assessing the behavior of mice in the 14 days of survey after drinking the test samples in maximum dose $D_{\max }$

\begin{tabular}{|c|c|c|}
\hline Organ systems & Observe and test & General signs \\
\hline $\begin{array}{l}\text { Central nervous system and } \\
\text { movement nervous system }\end{array}$ & Behavior, movement & $\begin{array}{l}\text { Mouse movement and normal eating activities } \\
\text { in the cage. Do not record states of agitation or } \\
\text { loss of reflexes, sleep, or coma }\end{array}$ \\
\hline Vegetative nervous system & $\begin{array}{l}\text { Brain and spinal cord reactions } \\
\text { Muscle strength } \\
\text { Eye-nose }\end{array}$ & $\begin{array}{l}\text { No abnormal expression } \\
\text { Normal } \\
\text { Normal }\end{array}$ \\
\hline Respiratory system & Characteristics and speed & $\begin{array}{l}\text { Normal breathing, not recognized symptoms of } \\
\text { dyspnea or convulsions trachea }\end{array}$ \\
\hline Cardiovascular system & Cardiovascular signs & Not noted abnormalities in heart rhythm \\
\hline Stomach, intestines & $\begin{array}{l}\text { The symptoms } \\
\text { Abdominal shape } \\
\text { Stiffness and color of stool }\end{array}$ & $\begin{array}{l}\text { Not recognized symptoms of diarrhea, } \\
\text { constipation. } \\
\text { Not recognized symptoms of abdominal twists } \\
\text { Normal mouse droppings. }\end{array}$ \\
\hline Genital & Penis & Pinky and puffed up \\
\hline Skin and fur & Color, status & $\begin{array}{l}\text { Silky white hair. No redness symptoms on the } \\
\text { skin or ruffling }\end{array}$ \\
\hline General condition & Weight gain & In normal physiological threshold \\
\hline
\end{tabular}

Table 5. The evaluation result of percent ratio increased the phenol red secretion of normal mice group and mice group caused cough using a capsaicin model

\begin{tabular}{lcccc}
\hline Experimental group $(\mathrm{n}=8-10)$ & $\begin{array}{c}\text { Oral dose } \\
(\mathrm{g} / \mathrm{kg})\end{array}$ & Optical density & $p$-value & $\begin{array}{c}\text { \% increased phenol } \\
\text { redness }\end{array}$ \\
\hline Distilled water control & - & $0.083 \pm 0.005$ & - & - \\
Ambroxol & 0.24 & $0.166 \pm 0.027$ & 0.004 & 99.70 \\
Concentrate product & 1.0 & $0.150 \pm 0.021$ & 0.026 & 80.96 \\
& 2.0 & $0.102 \pm 0.013$ & 0.409 & 23.01 \\
Spray-dried powder & 1.5 & $0.164 \pm 0.022$ & 0.008 & 97.47 \\
& 3.0 & $0.102 \pm 0.014$ & 0.682 & $\%$ increased phenol \\
Experimental group $(\mathrm{n}=9)$ & Oral dose & Optical density & $p$-value & - \\
\hline Physiological control & $(\mathrm{g} / \mathrm{kg})$ & - & - & $\downarrow 30.27$ \\
Capsaicin control & - & $0.086 \pm 0.004$ & $0.008^{*}$ & $\uparrow 54.55$ \\
Neo-codion $\circledast$ & - & $0.060 \pm 0.007$ & $0.016^{\#}$ & $\uparrow 55.29$ \\
Concentrate product & 1 tablet/kg & $0.093 \pm 0.010$ & $0.043^{\#}$ & $\uparrow 65.68$ \\
Spray-dried powder & 1.0 & $0.093 \pm 0.013$ & $0.006^{\#}$ & \\
\hline
\end{tabular}

Notes: *: compare with physiological control; \#: compare with pathological control.

codion ${ }^{\circledR}$ formula all work to treat coughs. Codeine is an alkaloid of opium fruit, an anti-cough drug which was effective on central nerous system and inhibition of respiratory center. Sulfogaiacol has the effect of secretions dilution in the respiratory mucosa and had effect on reducing phlegm. Ethanol extract Grindélia has anti-cough effect. Concentrated product (dose of $1.0 \mathrm{~g} / \mathrm{kg}$ ) and spray-dried powder (dose of $1.5 \mathrm{~g} / \mathrm{kg}$ ) all showed the effect of increasing red phenol secretion in the trachea of white mice caused by capsaicin, with an increase of $55.29 \%$ and $65.68 \%$, reaching statistical significance compared to the batch of capsaicin and not significantly different from the physiological control group. The effect of reducing phlegm of the samples of Pouzolzia zeylanica is similar to the effect of Neocodion ${ }^{\circledR}$. 


\section{Cough suppressant effects of two test products}

Capsaicin (8-methyl-N-vanillyl-6-nonenamide), a spicy ingredient in chilli, has long been used to stimulate coughing in a safe way, depending on the dosage used to show different levels of cough, this can reflect the reaction of nerve fibers (C-fiber) in the lining of the respiratory tract. The results in Table 6 have shown that powder sample $(1.5 \mathrm{~g} / \mathrm{kg}$ dose) prolonged the occurrence of cough symptoms in mice groups, which caused cough using capsaicin model, significantly different from the batch of control capsaicin. The occurrence time of cough symptoms in mice group using $\mathrm{Neo}-\operatorname{codion}{ }^{\circledR}$ or concentrated product (dose of $1 \mathrm{~g} / \mathrm{kg}$ ) was not statistically significant difference $(p>0.05)$ compared to the capsaicin control group.

The results in Table 7 showed that Neocodion ${ }^{\circledR}$ drug reduced the number of sneezing and brushing feather at the muzzle of mice using capsaicin model, which was statistically different from the batch of control capsaicin. But the number of sneezing and combing feather at the muzzle of mice drinking concentrated product (dose of $1 \mathrm{~g} / \mathrm{kg}$ ) or spray-dried powder (dose of $1.5 \mathrm{~g} / \mathrm{kg}$ ) had a reduced, which did not reach statistical significance compared to the control capsaicin experimental group.
The results in Table 8 also showed that the spray-dried powder ( $1.5 \mathrm{~g} / \mathrm{kg}$ dose $)$ had similar effect of Neo-codion ${ }^{\circledR}$ drug reduced the number of jumps due to stimulation caused using capsaicin coughing model, statistically significant difference from the batch of control capsaicin. However, the number of jumps due to stimulation in rats taking concentrated product (dose of $1 \mathrm{~g} / \mathrm{kg}$ ) was not statistically significantly from the control capsaicin experimental group.

\section{CONCLUSION}

The two tested products did not exhibit oral tract acute toxicity when evaluated in white mice. At the same time, the two products did not have antibacterial activity against the 5 selected strains of bacteria (Staphylococcus aureus, Streptoccocus pyogenes, Streptococcus pneumoniae, Klebsiella pneumoniae, Pseudomonas aeruginosa), which were related with diseases of respiratory tract except, spray-dried powder.

The spray-dried powder had antibacterial activity on strains of Streptococcus pyogenes with a minimum inhibitory concentration (MIC) of $50 \mathrm{mg} / \mathrm{mL}$; at dose of $6 \mathrm{~g} /$ day converted in humans,

Table 6. The evaluation result of the time that appear cough symptoms of mice group caused cough using a capsaicin model

\begin{tabular}{lccc}
\hline Experimental group $(\mathrm{n}=8)$ & Oral dose $(\mathrm{g} / \mathrm{kg})$ & Time $($ seconds) & $p$-value \\
\hline Capsaicin control & & $1.63 \pm 0.26$ & - \\
Neo-codion® & 1 tablet $/ \mathrm{kg}$ & $1.75 \pm 0.25$ & 0.736 \\
Concentrate product & 1.0 & $2.38 \pm 0.26$ & 0.063 \\
Spray-dried powder & 1.5 & $2.88 \pm 0.52$ & 0.049 \\
\hline
\end{tabular}

Table 7. The evaluation result of the number sneezing and brushing feather at muzzle of mice group caused cough using a capsaicin model

\begin{tabular}{lccc}
\hline Experimental group $(\mathrm{n}=8)$ & Oral dose $(\mathrm{g} / \mathrm{kg})$ & Times number & $p$-value \\
\hline Capsaicin control & & $126.0 \pm 13.90$ & - \\
Neo-codion $®$ & 1 viên $/ \mathrm{kg}$ & $78.75 \pm 5.44$ & 0.007 \\
Concentrate product & 1.0 & $102.38 \pm 9.25$ & 0.179 \\
Spray-dried powder & 1.5 & $115.13 \pm 13.11$ & 0.578 \\
\hline
\end{tabular}

Table 8. The evaluation result of the number jumps due to stimulation of mice group caused cough using a capsaicin model

\begin{tabular}{lccc}
\hline Experimental group $(\mathrm{n}=8)$ & Oral dose $(\mathrm{g} / \mathrm{kg})$ & Number of jumps & $p$-value \\
\hline Capsaicin control & & $21.38 \pm 4.02$ & - \\
Neo-codion $®$ & 1 tablet $/ \mathrm{kg}$ & $10.13 \pm 2.89$ & 0.039 \\
Concentrate product & 1.0 & $12.0 \pm 3.53$ & 0.101 \\
Spray-dried powder & 1.5 & $9.25 \pm 3.10$ & 0.032 \\
\hline
\end{tabular}


it had effect on reducing sputa and cough symptom due to stimulation of cough model with capsaicin.

The concentrated product did not show antimicrobial activity in bacterial strains related with respiratory tract disease; at a dose of $4 \mathrm{~g}$ /day converted in humans, it had effect on reducing sputa in experimental mice affected with capsaicin, but the effect of it on cough symptoms caused by the capsaicin model was not typical in comparison with spray-dried powder.

\section{ACKNOWLEDGEMENTS}

The authors gratefully acknowledge the Research Centre of Ginseng and Medicinal Material, Department of Microbiology, Medicine and Pharmacy University in Ho Chi Minh City, Vietnam that supported the implementation of this research.

\section{REFERENCES}

Adeleye, I.A., Onubogu, C.C., Ayolabi, C.I., Isawumi A.O. \& Nshiogu, M.E. 2008. Screening of crude extract of twelve medicinal plants and "wondercure" concotion used in Nigeria unorthodox medicine for activity against Mycobacterium tuberculosis isolated from tuberculosis patient sputum. African Journal of Biotechnology, 7: 3182- 3187.

Anyanwu, M.U. \& Okoye, R.C. 2017. Antimicrobial activity of Nigerian medicinal plants. Journal of Intercultural Ethnopharmacology, 6(2): 240259.

Balouiri, M., Sadiki, M. \& Ibnsouda, S.K. 2016. Methods for in vitro evaluating antimicrobial activity: A review. Journal of Pharmceutical Analysis, 6: 71-79.

Bello, I.A., Ndukwe, G.J., Audu, O.T. \& Habiba, J.D. 2011. A bioactive flavonoid from Pavetta crassipes K. Schum. Organic and Medicinal Chemistry Letters, 1: 14.

Bhattacharjya, D.K. \& Borah, P.C. 2008. Medicinal weeds of crop fields and role of women in rural health and hygiene in Nalbari district, Assam. Indian Journal of Traditional Knowledge, 7(3): 501-504.

Canning, B.J. 2008. Canning The cough reflex in animals: Relevance to human cough research. Lung, 186(Suppl 1): S23-S28. doi:10.1007/ s00408-007-9054-6.

Dapaah, G., Koffuor, G.A., Mante, P.K. \& Ben, I.O. 2016. Antitussive, expectorant and analgesic effects of the ethanol seed extract of Picralima nitida (Stapf) Th. \& H. Durand. Research in Pharmaceutical Science, 11(2): 100-112.
Do, T.D. 1996. Methods for determining acute toxicity of drugs. Medical Publishing House. pp. 7-51.

Engler, H. \& Szelenyi, I. 1984. Tracheal phenol red secretion a new method for screening mucosecetolyic compounds. Journal Pharmacological Methods, 11: 151-157.

Ernest, E. 2004. Os riscos de produtos de fitoterapia. Farmacoterapia e Seguranca da Droga, 13: 767-771.

Ikegbunam, M.N., Anagu, L.O., Nwakile, D.C., Afunwa, A.R. \& Esimone, C.O. 2014. Antimicrobial activity of selected medicinal plants of South-Eastern Nigeria on Pseudomonas species expressing extended spectrum betalactamase (ESBL). European Journal of Medicinal Plants, 4: 1367-1377.

Le, T.T. 2007. Preliminary Test of Chemical Components for Pouzolzia zeylanica L. Benn. (Master). University of Natural Science, HCM City.

Li, T.S.C. 2006. Taiwanese Native Medicinal Plants, Phytopharmacology and Therapeutic Values. CRC Taylor \& Francis Group, LLC.

Modarresi-Chahardehi1, A., Ibrahim, D., FarizaSulaiman, S. \& Mousavi, L. 2012. Screening antimicrobial activity of various extracts of Urtica dioica. International Journal of Tropical Biology, 60(4): 1567-1576.

Mondal, P., Bhuyan, N., Das, S., Kumar, M., Barah, S. \& Mahato, K. 2013. Herbal medicines useful for the treatment of diabetes in North-East India: A review. International Journal of Pharmacy and Biological Sciences, 3(1): 575-589.

Nasir, B., Fatima, H., Ahmed M. \& Haq, I.U. 2015. Recent trends and methods inantimicrobial drug discovery from plant sources. Austin Journal of Microbiology, 1(1): 1-12.

National Institute of Medicinal Materials, Ministry of Health. 2006. Research Method of Pharmacological Effects of Drugs from Herbal. Science and Technics Publishing House, Hanoi. pp. 220387.

Nduche, M.U., Iwuoha, C.D. \& Igbokwe, A.U. 2016. Antibacterial activity of four Nigerian medicinal plants. Scholar Journal of Agriculture and Veterinary Sciences, 3: 172-180.

Nieto, L., de Diego, A., Perpiñá, M., Compte, L., Garrigues, V., Martínez, E. \& Ponce. J. 2003. Cough reflex testing with inhaled capsaicin in the study of chronic cough. Respiratory Medicine, 97(4): 393-400.

Okwu, D.E. \& Nnamdi, F.U. 2011. Cannabinoid dronabinol alkaloid with antimicrobial activity from Cassia alata Linn. Der Chemica Sinica, 2(2): $247-254$. 
Omogbai, B.A. \& Eze, F.A. 2011. Phytochemical screening and susceptibility of bacteria pathogens to extracts of Evolvulus alsinoides. Science World Journal, 6(1): 5-8.

Patel, J.B., Cockerill, F.R., Hindler, J.A. \& Jenkins, S.G. 2015. Methods for dilution antimicrobial susceptibility test for bacteria that grow aerobically (M07-A10). Clinical and Laboratory Standards Institute, 35(2): 15-581.

Purkayastha, J., Dutta, M. \& Nath, S.C. 2007. Ethnomedicinal plant from Dibru-Saikhowa biosphere reserve, Assam. Indian Journal of Traditional Knowledge, 6(3): 477-480.

Ratnam, K.V. \& Raju, R.R.V. 2008. Traditional medicine used by the adivasis of Eantern Ghats, Andhra Pradesh - for bone fractures. Ethnobotanical Leaflets, 12: 19-22

Rietjens, I.M.C.M., Boersma, M.G., Van Der Woude, H., Jeurissen, S.M.F., Schutte, M. \& Alink, G.M. 2005. Flavonoids and alkenylbenzenes: mechanisms of mutagenic action and carcinogenic risk. Mutation Research, 574: 124-138.

Sandhya, S., Venkata, R.K., Vinod, K.R., Swapna, R. \& Asia, B. 2013. Scope of medicinal flora as effective anti ulcer agents. African Journal of Plant Science, 7(11): 504-512.

Satia, I., Tsamandouras, N., Holt, K., Badri, H., Woodhead, M., Ogungbenro, K., Felton, T.W., O’Byrne, P.M., Fowler, S.J. \& Smith, J.A. 2017. Capsaicin-evoked cough responses in asthmatic patients: Evidence for airway neuronal dysfunction. Journal of Allergy and Clinical Immunology, 139(3): 771-779.

Shah, G.M., Hussain, M. \& Abbas, A.M. 2015. Medicinal plants used to treat respiratory tract illness in Kaghan Valley, Himalayan RegionPakistan. Retrieved from http://www.smge books.com/allergic-diseases/chapters/AD-1501.pdf.
Simão, A.A., Corrê, A.D., Preté, P.S.C., Queiroz, E.D.R., Cesar, P.H.S., Oliveira, C.H.D.M. \& Marcussi, S. 2014. Pharmacotoxic evaluation of extracts of medicinal plants used in the treatment of obesity. African Journal of Pharmacy and Pharmacology, 8(43): 11031109.

Tanaka, M. \& Maruyama, K. 2005. Mechanisms of capsaicin- and citric-acid-induced cough reflexes in guinea pigs. Journal of Pharmacological Science, 99: 77-82.

Van-Vuuren, S.F., Nkwanyana, M.N. \& Wet, H.D. 2015. Antimicrobial evaluation of plants used for the treatment of diarrhoea in a rural community in northern Maputaland, KwaZuluNatal, South Africa. BMC Complementary and Alternative Medicine, 15(53).

Vo Van Chi. 2012. Dictionary of Medicinal Plants in Vietnam. Medical Publishing House. pp. 189191.

Yusuf, M., Wahab, M.A., Chowdhury, J.U. \& Begum, J. 2006. Ethno-medico biotanical knowledge from kaukhali proper and betbunia of rangamati district. Bangladesh Journal Plant Taxon, 13(1): 55-61.

Zhang, J.L., Wang, H., Chen, C., Pi, H.F., Raun, H.L., Zhang, P. \& Wu, J.Z. 2009. Addictive evaluation of cholic acid-verticinone ester, a potential cough therapeutic agent with agonist action of opioid receptor. Acta Pharmacologica Sinica, 30(5): 559-566. 
